\title{
Biology Teachers' Understanding of Argument- Driven Inquiry and Think Pair Share Learning Model Based on the Educational Background and Teachers' Experience
}

\author{
Opnofti Prihandayu ${ }^{1, *}$ Paidi $^{2}$ \\ ${ }^{1}$ Master of Biology Education, Faculty of Mathematics and Natural Sciences, Universitas Negeri Yogyakarta, \\ Indonesia \\ 2 Department of Biology Education, Faculty of Mathematics and Natural Sciences, Universitas Negeri \\ Yogyakarta, Indonesia \\ *Corresponding author. Email: opnoftiprihandayu.2019@student.uny.ac.id
}

\begin{abstract}
This research was a descriptive study with a census method that aims to describe the biology teachers' understanding of Argument-Driven Inquiry and Think Pair Share learning model based on the educational background and teachers' experience. This research used the research subject were 37 teachers, they were all biology teachers of class X, XI, and XII at public senior high school/islamic senior high school in Kebumen Regency. The instrument is used a multiple-choice test releated to the understanding of learning model. Data analysis was carried out descriptive by determining the mean score of the biology teachers' understanding based on understanding criteria which consisted of 5 categories. The results showed that the biology teachers' understanding score of the Argument-Driven Inquiry learning model was moderate and the biology teachers' understanding score of the Think Pair Share learning model was very high. The analysis based on educational background shows that teachers with an educational background from the education field was higher understanding than from non-educational fields. The analysis based on teachers' experience shows that biology teachers in the work period of 11-20 years have the highest understanding compared to those who work for 1-10 years and 11-30 years.
\end{abstract}

Keywords: Teachers' understanding, Argument-driven inquiry, Think pair share, Educational background, Tearhers' experience

\section{INTRODUCTION}

Education is currently facing very complex challenges in preparing the quality of human resources that can compete globally [1]. The 2013 curriculum with its various improvements has answered the current education challenge, because the 2013 curriculum has accommodated 21st-century skills, both in terms of content standards, process standards, and assessment standards [2]. The standard of process arranges that education must apply scientific learning, meaning that it emphasizes the active involvement of students in scientific activities during the learning process, including in biology learning.

The efforts to create an active biology learning situation, one of which can be done by selecting and implementing the right learning model, that is a learning model that can optimize the motivation of students to participate more fully in the learning process. Then, the use of a variety of learning models can create an effective learning process [3]. This is in line with the NEA statement in 2008 regarding the challenges of learning in the $21^{\text {st }}$ century, which is the need to emphasize the development of core skills which include critical thinking and problem solving, collaboration, communication, and creativity and innovation in the learning process [4]. Therefore, teachers who are adaptive to change and sensitive to the needs of the times are needed. The role of the teacher is very important to note to support the successful application of the learning model.

The teacher's role in learning biology begins with the design of learning activities so that a biology 
learning process is created by the demands of the curriculum to face today's educational challenges. Teachers play an important role in innovating the learning process so that it has a positive influence on the quality of education for the future [5], [6], [7]. This is reinforced by several research results which reveal that teachers hane made a major contribution to improving the quality of education in many countries [8]. Good quality of education is influenced by professional teaching staff [9], [10], [11].

Teachers' professionalism can be shown by several indicators that must-have, that is understanding the insight and educational foundation, mastery of design learning, mastery of implementation learning, and mastery of evaluating student learning outcomes [12]. In this case, it means that biology teachers need to have an understanding of their active role in improving the quality of learning, one of which is an understanding of learning models [13]. Understanding is a person's ability to grasp the meaning of something that has been learned as a result of the use of the senses [14], [15]. Regarding the understanding of learning models, alternative learning models that can answer learning challenges along with the times in the $21 \mathrm{st}$ century by biology teachers include the ArgumentDriven Inquiry and Think Pair Share learning models.

Argument-Driven Inquiry is a learning model that provides opportunities for students to design scientific investigation activities as an effort to develop, understand, or evaluate scientific explanations of natural phenomena, to develop critical thinking skills [16], [17], [18]. The Argument-Driven Inquiry learning model emphasizes inquiry activities as an effort to solve problems so that it is effective in increasing academic achievement and science process skills through scientific inquiry and argumentation activities [19], [20]. Then, Think Pair Share is a learning model that involves pair discussion activities [21], so that it can increase the active role of students in the learning process [22] and improve communication skills and students' motivation to learn [23], [24].

Teachers' understanding of the learning model is part of the pedagogical competencies that teachers must have to build quality learning and improve student competencies as a result of achieving learning objectives [6]. One of the abilities of teachers to design a quality learning process is obtained from quality experience [25]. Experience can be gained both during the study period and during the work period. In this case, the educational background and teachers' experience can be one of the factors that influence teachers' understanding of the learning model.
The first step that can be taken to develop quality learning is knowing the initial description of the teacher's understanding of the learning model. One way that can be used to find out the teacher's understanding of the learning model is to conduct a analysis of the teachers' understanding regarding the Argument-Driven Inquiry and Think Pair Share learning model based on educational background and teachers' experience.

So far there is no information about the biology teachers' understanding of the Argument-Driven Inquiry and Think Pair Share learning model based on educational background and teachers' experience. Therefore, the analysis of biology teachers' understanding of the Argument-Driven Inquiry and Think Pair Share learning model is based on educational background and teachers' experience is important and interesting to do to obtain an empirical picture of the level of biology teachers' understanding on the learning models.

\section{RESEARCH METHOD}

\subsection{Research Design}

This research was a descriptive study with a census method that aims to describe the biology teachers' understanding of the Argument-Driven Inquiry and Think Pair Share learning model was based on the educational background and teachers' experience. The understanding was detailed due to Blooms' taxonomy, that covers: interpreting, exemplifying, classifying, summarizing, inferring, comparing, and explaining [26]. This research was conducted in Kebumen Regency on August 2020. The subject of this research was all biology teachers of class X, XI, and XII public senior high school/islamic senior high school in Kebumen Regency, totaling 37 people, according to the Dapodik system of the Kebumen Regency education office.

\subsection{Data Collection Techniques and Instruments}

This research emphasizes obtaining primary data about the biology teachers' understanding of the Argument-Driven Inquiry and Think Pair Share learning model based on the educational background and teachers' experience. Primary data were obtained directly from the study population using a data collection technique in the form of a multiple-choice test. The test instrument used is in the form of an understanding test based on Blooms' taxonomy, which is interpreting, exemplifying, classifying, summarizing, inferring, comparing, and explaining 
[26]. The test instrument was tested first and validity and reliability were tested. The validity test was based on expert judgment. The reliability test was based on the empirical test. The instrument then was categorized a reliable with the $\mathrm{r}$ of 0,701 .

\subsection{Research Data Analysis Techniques}

Data analysis was carried out descriptivel by determining the mean score of the biology teachers' understanding of the Argument-Driven Inquiry and Think Pair Share learning model based on understanding criteria consisting of 5 categories according to the category of teachers' understanding [27] as in Table 1.

Table 1. Rating category of teachers' understanding

\begin{tabular}{|c|c|}
\hline \multicolumn{1}{|l|}{ Score } & Category \\
\hline $75<\mathrm{X}$ & Very high (excelent) \\
\hline $58.35<\mathrm{X} \leq 75$ & High (good) \\
\hline $41.65<\mathrm{X} \leq 58.35$ & Moderate (fair) \\
\hline $25<\mathrm{X} \leq 41.65$ & Low (poor) \\
\hline $\mathrm{X}<25$ & Very low (very poor) \\
\hline
\end{tabular}

The biology teachers' understanding at public senior high school/islamic senior high school in Kebumen Regency towards the Argument-Driven Inquiry and Think Pair Share learning model is analyzed based on educational background and teachers experience.

The analysis of the biology teachers' understanding based on the educational background was divided into 2 groups, that is a group of biology teachers with the latest education in the field of education and biology teachers with the latest education in the non-field education. Analysis of the biology teachers' understanding based on experience was divided into 3 groups, that is the biology teacher group with experience of 1-10 years, 11-20 years, and 21-30 years.

\section{RESULTS AND DISCUSSION}

\subsection{The Biology Teachers' Understanding of The Argument-Driven Inquiry and Think Pair Share Learning Model}

The results of the research of the biology teachers' understanding of the Argument-Driven Inquiry and Think Pair Share learning model at public senior high school/islamic senior high school in Kebumen Regency regarding can be seen in Table 2.

The results of research on the general profile of the biology teachers' understanding of the ArgumentDriven Inquiry learning model on Table 2 show the mean score of biology teacher tests of 48 with the acquisition of a maximum score of 70 , the minimum score is 20, and the standard deviation is 11.26. Based on the mean score of understanding obtained, it means that the level of biology teachers' understanding at public senior high school/islamic senior high school in Kebumen Regency towards the Argument-Driven Inquiry learning model is moderate. Then, the mean score of the biology teachers' understanding of the Think Pair Share learning model is 83 with a maximum score of 100 , a minimum score of 40 , and a standard deviation of 15.03. Based on the mean score of understanding obtained, it means that the level of biology teachers' understanding at public senior high school/islamic senior high school in Kebumen Regency about the Think Pair Share learning model is very high.

The results showed that the biology teachers' understanding at public senior high school/islamic senior high school in Kebumen Regency about the Think Pair Share learning model was higher than the understanding of the Argument-Driven Inquiry learning model. This can happen because $57 \%$ of the biology teachers stated that they had never heard of the Argument-Driven Inquiry learning model, while only $19 \%$ of the biology teachers stated that they did not know about the Think Pair Share learning model.

Think Pair Share learning model is more familiar among biology teachers at public senior high school/islamic senior high school in Kebumen Regency compared to the Argument-Driven Inquiry learning model. This can be because the ArgumentDriven Inquiry learning model is a model that has not been developed for a long time in the learning process of biology. The Argument-Driven Inquiry learning model is a learning model designed in 2009 by Sampson and Gleim as a learning model aimed at training scientific argumentation skills to improve students' critical thinking skills [3]. A teacher who states that he has never heard of the Argument-

Driven Inquiry learning model means that he doesn't have information about the learning model, so he has a low level of understanding. Information is important because the information obtained is a source of knowledge [28].

\subsection{The Biology Teachers' Understanding of Argument-Driven Inquiry and Think Pair Share Learning Models Based on The Aspects of The Learning Model}

The biology teachers' understanding of the Argument-Driven Inquiry and Think Pair Share learning model can be reviewed based on aspects of the learning model that have been adjusted to the dimensions of understanding based on Bloom's 
Table 2. The general profile of the biology teachers' understanding of the argument-driven inquiry and think pair share learning model

\begin{tabular}{|l|c|c|c|c|c|c|}
\hline \multirow{2}{*}{ Learning model } & \multirow{2}{*}{$N$} & \multicolumn{3}{|l|}{ Teachers' understanding score } & \multirow{2}{*}{ Category } \\
\cline { 3 - 7 } & & Mean & Max & Min & Std. Dev & \\
\hline Argument-Driven Inquiry & 37 & 48 & 70 & 20 & 11.26 & Moderate \\
\hline Think Pair Share & 37 & 83 & 100 & 40 & 15.05 & Very high \\
\hline
\end{tabular}

taxonomy. This study only discusses the six dimensions of understanding from the seven dimensions of understanding, that is the dimensions of interpreting, exemplifying, classifying, summarizing, inferring, and comparing [26].

\subsubsection{Biology Teachers' Understanding of The Argument-Driven Inquiry Learning Model Based On Aspects of The Argument-Driven Inquiry Learning Model}

The results of the research on the biology teachers' understanding at public senior high school/islamic senior high school in Kebumen Regency towards the Argument-Driven Inquiry learning model is based on aspects of the learning model can be seen in Table 3 .

The results of the research on biology teachers' understanding of the Argument-Driven Inquiry learning model at public senior high school/islamic senior high school in Kebumen Regency is based on the aspects of the split model in Table 3 show that the mean score of biology teachers' understanding in the aspect of the definition learning model is 32.43 (low), on the learning model application aspect of 40.53 (low), the syntactic aspect of the learning model is 41.89 (moderate), the characteristic aspect of the learning model is 54.05 (moderate), the assessment system aspect the learning model is 72.92 (high/good), and the strengths and weaknesses of the learning model are 56.77 (moderate). Based on the results of the mean score of understanding biology teachers in every aspect of understanding the Argument-Driven Inquiry learning model, it shows that the biology teachers have the lowest level of understanding on the aspects of understanding the learning model and have the highest understanding of the aspects of the learning model assessment system. The level of understanding of biology teachers on aspects of the Argument-Driven Inquiry learning model is shown based on the results of comprehension tests that have been conducted by every biology teacher in Kebumen Regency.

The understanding of biology teachers in the aspect of understanding the model is still low because $68 \%$ of biology teachers have not been able to interpret the understanding of the Argument-Driven Inquiry learning model is correct. This shows that the understanding of the biology teacher's initial concept of the model tends to below. The understanding of biology teachers on the assessment system aspects of the learning model is classified as high because the majority of biology teachers can predict the appropriate assessment system applied in the learning process using the Argument-Driven Inquiry learning model.

The understanding of biology teachers in the application aspect of the learning model is relatively low because $59 \%$ of biology teachers have not been able to provide examples of biology subject matter that can be studied using the Argument-Driven Inquiry learning model. The understanding of biology teachers on the syntactic aspect of the learning model is classified as moderate because $57 \%$ of biology teachers have not been able to categorize the activities that must be carried out by both teachers and students at each activity step in the stage of the Argument-Driven Inquiry learning model correctly. The teachers' understanding of the stages of the learning model can affect the ability of teachers to design learning activities. Teachers who have an understanding of the moderate category of the stages of learning model activities are assumed to have less

Table 3. Biology teachers' understanding of the argument-driven inquiry learning model based on the aspects of the argument-driven inquiry learning model

\begin{tabular}{|l|l|c|c|}
\hline Understanding dimension & $\begin{array}{l}\text { The aspect of the Argument-Driven } \\
\text { Inquiry learning model }\end{array}$ & Mean & Category \\
\hline Interpreting & Definition & 32.43 & Low \\
\hline Exemplifying & Application & 40.53 & Low \\
\hline Classifying & Syntax & 41.89 & Moderate \\
\hline Summarizing & Characteristic & 54.05 & Moderate \\
\hline Inferring & Assessment system & 72.92 & High \\
\hline Comparing & Strengths and weaknesses & 56.76 & Moderate \\
\hline
\end{tabular}


than optimal abilities in designing learning process activities. Then, the understanding of biology teachers on the characteristics of the learning model is moderate because $54 \%$ of biology teachers can abstract and generalize the characteristics of the Argument-Driven Inquiry learning model to properly. The biology teachers' understanding of the strengths and weaknesses aspect of the learning model is moderate because $57 \%$ of biology teachers can compare the strengths and weaknesses of the Argument-Driven Inquiry learning model with other learning models.

\subsubsection{Biology Teachers' Understanding of The Think Pair Share Learning Model Based On The Aspects of Learning Model}

The results of research on the biology teachers' understanding at public senior high school/islamic senior high school in Kebumen Regency regarding the Think Pair Share learning model is based on the aspects of the learning model can be seen in Table 4 .

The results of the research on biology teachers' understanding of the Think Pair Share learning model is based on aspects of the learning model in Table 4 show that the mean score of biology teachers' understanding in the defining aspect of the learning model is 97,30 (very high), in the applying aspect of the learning model is 59.46 (high), in the syntactic aspect of the learning model as large as 85.14 (very high), on the characteristic aspect of the learning model of 51.35 (moderate), in the assessment system aspect of the learning model is 97.30 (very high), and the strengths and weaknesses aspect of the learning model are 90.54 (very high). Based on the results of the mean score of the biology teachers' understanding based on understanding aspect of the Think Pair Share learning model, it shows that the biology teacher has the lowest level of understanding on the characteristic aspects of the learning model and has the highest level of understanding on the definition and assessment systems aspect of the learning model. The level of the biology teachers' understanding of the aspects of the Think Pair Share comprehension tests that have been conducted by each biology teacher.

The biology teachers' understanding of the aspects of definition and assessment systems for the learning model was classified as very high. It was evidenced by $97 \%$ of biology teachers who could translate the Think Pair Share learning model meaning and predict the appropriate assessment system to be applied in the learning process using the Think Pair Share learning model appropriately. The very high understanding of this learning model's definition aspect revealed that most biology teachers had very good initial concepts of the Think Pair Share learning model. In the aspect of the learning model characteristics, the biology teachers' understanding was moderate because $49 \%$ of them did not know the Think Pair Share learning model's characteristics. Furthermore, in the aspect of implementing the learning model, the biology teachers' understanding was high. It was proven by $59 \%$ of them could determine the appropriate biology learning material to be studied using the Think Pair Share learning model.

In the learning model's syntactic aspect, the biology teachers' understanding was very high. It was demonstrated by $85 \%$ of biology teachers could correctly state the stages that had to be applied in the Think Pair Share learning model based on the right order. Besides, they could categorize and explain the activities carried out by both teachers and students at each activity steps in the Think Pair Share learning model syntax appropriately. The biology teachers' understanding of the learning model stages could affect their ability to plan learning activities. The biology teacher of at public senior high school/islamic senior high school in Kebumen Regency, who had a very high understanding of the Think Pair Share learning model activities' stages, should have an excellent ability in designing activities in the biology learning process. Furthermore, the biology teachers' understanding learning model about that strengths and weaknesses aspect was very high, shown by $91 \%$ of them could compare the Think Pair Share learning model's

Table 4. Biology teachers' understanding of the think pair share learning model based on the aspects of the think pair share learning model

\begin{tabular}{|l|l|c|c|}
\hline Understanding dimension & $\begin{array}{l}\text { The aspect of the Think Pair Share } \\
\text { learning model }\end{array}$ & Mean & Category \\
\hline Interpreting & Definition & 97.30 & Very high \\
\hline Exemplifying & Application & 59.46 & High \\
\hline Classifying & Syntax & 85.14 & Very high \\
\hline Summarizing & Characteristic & 51.35 & Moderate \\
\hline Inferring & Assessment system & 97.30 & Very high \\
\hline Comparing & Strengths and weaknesses & 90.54 & Very high \\
\hline
\end{tabular}

learning model is shown based on the results of the strengths and weaknesses with other learning models. 


\subsection{Biology Teachers' Understanding of The Argument-Driven Inquiry and Think Pair Share Learning Model Based On The Educational Background}

The biology teachers' understanding of the Argument-Driven Inquiry and Think Pair Share learning model at public senior high school/Islamic senior high school in Kebumen Regency can be reviewed based on the educational background that the teacher has taken, that is the group of biology teachers with educational backgrounds in the field of education and the group of biology teachers with educational backgrounds in the non-educational field. The results of these studies can be seen in Table 5 .

The results of the research on biology teachers' understanding of the Argument-Driven Inquiry learning model on Table 5 show that the mean score of the biology teachers' understanding with an educational background in the field of non-education is 41.42 (low), while the mean score of biology teachers' understanding with an educational background in the field of education is 49.33 (high). The results of the research about biology teachers' understanding of the Think Pair Share learning model in Table 5 shows that the mean score of biology teachers' understanding with an educational background in the non-educational field is 74.28 (high), while the mean score of the biology teachers' understanding with a background behind education in the education sector is 84.67 (very high).

The results uncovered that the biology teachers' understanding at public senior high school/Islamic senior high school in Kebumen Regency with an educational background from the education field was higher than from non-educational fields, both for the Argument-Driven Inquiry and Think Pair Share learning models. The non-educational biology teachers' understanding tended to be lower. It could be caused by the mismatch between the educational background and the profession being undertaken. This discrepancy was indicated by the existence of a biology teacher with an educational background of Agriculture graduate (S.Pt). Teachers are required to have minimum qualifications that must be met and proven by a relevant diploma or certificate of expertise [29]. It means that as a teacher who works in an educational institution, she should come from a Bachelor of Education (S.Pd.).

An unsuitable teacher educational background could result in low teacher pedagogical competence. This low competence can be used to measure the teacher's low understanding of the learning model because this competence reflects a teacher's basic teaching ability shown in learning activities. Pedagogic competence, which includes pedagogical knowledge and intelligence, could affect teachers' quality in implementing the learning process [30]. The low of biology teachers' understanding with educational backgrounds from non-educational fields about learning models than teachers from the education field could also be due to differences in the course offerings taken at the higher education level. Biology teachers with educational backgrounds in the education field were equipped with courses that include educational materials such as materials related to learning models to support professional competence and pedagogical competence as prospective teachers. A good educational process could produce competent teachers [31].

\subsection{Biology Teachers' Understanding of The Argument-Driven Inquiry and Think Pair Share Learning Model Based On Teachers' Experience}

The biology teachers' understanding of the Argument-Driven Inquiry and Think Pair Share learning model can be reviewed based on teacher experience. The working period is the time span or length of time a person works at a certain institution to hold certain positions or tasks based on the position they have. In this study, the working experience group was divided into 3 groups with a span of 10 years in each group of teachers' experience which is 1-10 years, 11-20 years, and 2130 years. The results of the research on the biology teachers' understanding of the Argument-Driven Inquiry and Think Pair Share learning model based on experience at public senior high school/islamic

Table 5. Biology teachers 'understanding of the argument-driven inquiry and think pair share learning model based on the educational background

\begin{tabular}{|c|c|c|c|c|c|c|c|}
\hline \multirow{2}{*}{ Learning model } & \multirow{2}{*}{$\begin{array}{l}\text { Educational } \\
\text { background }\end{array}$} & \multirow{2}{*}{$\mathbf{N}$} & \multicolumn{3}{|l|}{$\begin{array}{l}\text { Biology teachers' understanding } \\
\text { score }\end{array}$} & \multirow{2}{*}{ Category } \\
\cline { 3 - 8 } & & Mean & Max & Min & Std. Dev & \\
\hline Argument-Driven \\
Inquiry & Non-educational & 7 & 41.42 & 60 & 20 & 15.74 & Low \\
\cline { 2 - 8 } & Educational & 30 & 49.33 & 70 & 30 & 9.44 & Moderate \\
\hline \multirow{2}{*}{ Think Pair Share } & Non-educational & 7 & 74.28 & 90 & 50 & 15.12 & High \\
\cline { 2 - 7 } & Educational & 30 & 84.67 & 100 & 40 & 14.56 & Very high \\
\hline
\end{tabular}


senior high school in Kebumen Regency can be seen in Table 6.

The results of the research on biology teachers' understanding of the Argument-Driven Inquiry learning model is based on teachers' experience at public senior high school/islamic senior high school in Kebumen Regency on Table 6 show that the mean score of biology teacher understanding in work period 1- 10 years is 40 (low), the work period is 1120 years is 50 (moderate), and in the 21-30 years is 51 (moderate).

The results of research on biology teachers' understanding of the Think Pair Share learning model based on teachers' experience in Table 6 show that the mean score of the biology teachers' understanding in a work period of 1-10 years is 75 (high), in a working period of 11-20 years of 86 (very high), and during the work period of 21-30 years it was 81 (very high).

The biology teachers' understanding of the Argument-Driven Inquiry and Think Pair Share learning model based on teachers' experience shows that biology teachers in the work period of 1-10 years have a lower level of understanding compared to biology teachers during the work period of 11-20 years and 21-30 years, both for Argument-Driven Inquiry learning model as well as the Think Pair Share learning model. One of the reasons for this is that biology teachers with experience of 1-10 years have less teaching experience than biology teachers with a working period of 11-30 years.

Meanwhile, the length of time working as a teacher will provide a different experience for each teacher. The longer the teachers' experience, the more experience is gained. Experience positively influences teachers' teaching ability [32]. A teacher, who had a relatively long teaching experience and a lot of teaching experience, tended to have a high level of ability and work performance [33]. These results are consistent with research, which stated that the longer the teachers' experience, the more learning experience would be obtained [34]. Besides, positive teaching experiences will determine the success of the learning process [35]. The longer a person works, the better the experience, which will result in an increase in understanding [36]. In this case, the experience is a source of information that can be constructed to increase knowledge [28].

The results of the study in Table 6 show that the mean score of biology teachers' understanding at public senior high school/islamic senior high school in Kebumen Regency regarding the learning model Think Pair Share in the 21-30 years working period is lower than that of biology teachers during the 11-20 years of work. This is not by the statement that the longer the working period, the more experience one has, so the better understanding will be. The results of this study indicate that other factors influence the level of understanding of teachers, one of which is age and motivation.

Biology teachers in the working period of 21-30 years have an age range of 48-60 years. Meanwhile, biology teachers in the working period of 11-20 years had an age range of 32-46 years. Teachers in the age range of 48-60 were assumed to be not following the development of information about innovative biology learning models according to the current development. It could occur because of a decrease in motivation to learn. Motivation is a change in a person's energy, marked by the emergence of feelings and reactions to achieve goals, giving rise to a sense of enthusiasm and persistence to achieve goals [37].

Teachers at the age of 48-60 years could experience a decrease in enthusiasm for work due to boredom. It is consistent with several studies that have been conducted, which disclosed that a long working period (more than 24 years) tended to result in a decrease in learning motivation because teachers tended to experience boredom [38], [39]. Teacher enthusiasm will decline with advancing age, which may be due to the boredom of teaching the same content for several years [32]. Besides, teachers' aged 55-65 years are the age group who have reached the pre-retirement stage. At that age, people will experience various stresses that affect immunological health, which results in a decrease in the intellectual potential of cognitive function in old age [40]. The

Table 6. Biology teachers' understanding of argument-driven inquiry and think pair share learning models based on teachers' experience

\begin{tabular}{|c|c|c|c|c|c|c|c|}
\hline \multirow{2}{*}{ Learning model } & \multirow{2}{*}{$\begin{array}{l}\text { Teachers' } \\
\text { experience (years) }\end{array}$} & \multirow{2}{*}{$\mathbf{N}$} & \multicolumn{4}{|c|}{$\begin{array}{l}\text { Biology teachers' understanding } \\
\text { score }\end{array}$} & \multirow{2}{*}{ Category } \\
\hline & & & Mean & Max & Min & Std. Dev & \\
\hline \multirow{3}{*}{$\begin{array}{l}\text { Argument-Driven } \\
\text { Inquiry }\end{array}$} & $1-10$ & 10 & 40 & 50 & 20 & 11.54 & Low \\
\hline & $11-20$ & 18 & 50 & 70 & 30 & 11.38 & Moderate \\
\hline & $21-30$ & 9 & 51 & 60 & 40 & 9.28 & Moderate \\
\hline \multirow{3}{*}{ Think Pair Share } & $1-10$ & 10 & 75 & 90 & 50 & 12.69 & High \\
\hline & $11-20$ & 18 & 86 & 100 & 70 & 9.79 & Very high \\
\hline & $21-30$ & 9 & 81 & 100 & 40 & 22.61 & Very high \\
\hline
\end{tabular}


highest mean score of biology teachers' understanding was in the 11-20 year age group with an age range of 32-46 years. It is consistent with research conducted by Martin and Smith in 1990, which affirmed that middle-aged teachers (working period 8-23 years) had a higher ability to learn [39], [41]. It was then reinforced by Alufohai and Ibhafidon in 2015, who elucidated that teachers aged 36 to 48 were the most effective ages in managing the class to improve student learning outcomes [42].

\section{CONCLUSION}

Based on the results of the study, it can be concluded that the biology teachers' understanding of the Argument-Driven Inquiry learning model at public senior high school/islamic senior high school in Kebumen Regency is classified as moderate. The biology teachers' understanding of public senior high school/islamic senior high school in Kebumen Regency regarding the Think Pair Share learning model is classified as very high. Different educational backgrounds result in different levels of the teachers' understanding of the Argument-Driven Inquiry and Think Pair Share learning model. The biology teachers' understanding at public senior high school/islamic senior high school in Kebumen Regency with educational backgrounds in the field of education is higher than the biology teachers' understanding with educational backgrounds in noneducational fields. Besides, the difference in a teaching experience that has been taken by the teacher also results in different levels of understanding of the Argument-Driven Inquiry and Think Pair Share learning model. Biology teachers with a work period of 1-10 years have a lower level of understanding than biology teachers with a working period of 11-30 years.

\section{ACKNOWLEDGMENTS}

The author would like thank to Allah SWT, and than like thank to Yogyakarta State University, the biology teacher of public senior high school/islamic senior high school in Kebumen Regency, and my family for their assistance, support, and collaboration during the research process.

\section{REFERENCES}

[1] P-A. Pertiwi, N. Hasnunidan, D. Lengkana, Pengaruh Model Pembelajaran ArgumentDriven Inquiry (ADI) terhadap Keterampilan Berpikir Kritis Peserta Didik, Jurnal Bioterdidik 7 (2019) 22-31.
[2] I.W. Redhana, Mengembangkan Keterampilan Abad Ke-21 dalam Pembelajaran Kimia, Jurnal Inovasi Pendidikan Kimia 13 (2019) 2239-2252.

[3] C.A. Safira, N. Hasnunidah, D. Sikumbang, Pengaruh Model Pembelajaran ArgumentDriven Inquiry (ADI) terhadap Keterampilan Argumentasi Siswa Berkemampuan Akademik Berbeda, Indonesian Journal of Biology Education 2 (2018) 46-51.

[4] A. A Educator and F. Cs, Preparing 21st Century Students for A Global Society, National Education Association, 2012.

[5] D. Goldman, B. Yavetz, S. Pe'er, Student Teachers' Attainment of Environmental Literacy in Relation to Their Disciplinary Major during Undergraduate Studies, International Journal of Environmental and Science Education 9 (2014) 369-383.

DOI: https://doi.org/10.12973/iji.2018.1113a

[6] S. Sudarisman, Memahami Hakikat dan Karakteristik Pembelajaran Biologi dalam Upaya Menjawab Tantangan Abad 21 serta Optimalisasi Implementasi Kurikulum 2013, Florea: Jurnal Biologi dan Pembelajarannya 2 (2015) 29-35. DOI: https://doi.org/10.25273/florea.v2i1.403

[7] F-A. Ningtiyas, Jailani, Does teacher's training affect the pedagogical competence of mathematics teachers?, in: Journal of Physics: Conference Series, vol. 1097, IOP Publishing, Bristol, 2018, pp. 1-6. DOI: https://doi.org/10.1088/1742$\underline{6596 / 1097 / 1 / 012106}$

[8] B-Y. Hu, X. Fan, Y. Yang, J. Neitzel, Chinese Preschool Teachers' Knowledge and Practice of Teacher-Child Interactions: The Mediating Role of Teachers' Beliefs About Children, Teaching and Teacher Education 63 (2017) 137-147. DOI: https://doi.org/10.1016/j.tate.2016.12.014

[9] A. Nolan, T. Molla, Supporting teacher Professionalism through Tailored Professional Learning, London Review of Education 17 (2019) 126-140. DOI: https://doi.org/10.18546/LRE.17.2.03

[10] B. Tütünis, D. Yalman, Teacher Education And Foreign Language Teacher Professionalism in The 21st Century, International Online Journal of Education and Teaching 7 (2020) 1168-1176. 
[11] W. Rimmer, A. Floyd, The Contribution Of Conferences to Teachers' Professionalism., The Electronic Journal for English as A Second Language 24 (2020) 1-17.

[12] R. Nurutami, A. Adman, Kompetensi Profesional Guru sebagai Determinan terhadap Minat Belajar Siswa, Jurnal Pendidikan Manajemen Perkantoran 1 (2016) 119. DOI: https://doi.org/10.17509/jpm.v1i1.3345

[13] S. Ramdiah, A. Abidinsyah, M. Royani, H. Husamah, Understanding, Planning, and Implementation of HOTS By Senior High School Biology Teachers in BanjarmasinIndonesia, International Journal of Instructon 12 (2019) 425-440. DOI: https://doi.org/10.29333/iji.2019.12128a

[14] H. Apriyanti, Pemahaman Guru Pendidikan Anak Usia Dini terhadap Perencanaan Pembelajaran Tematik, Journal of Early Childhood Education 48 (2009) 111-117. DOI: https://doi.org/10.1143/JJAP.48.024501

[15] P. Paidi, D. Djukri, S. Yulaikah, D. Alfindasari, Development of Instrument to Assess Cognitive Process and Product in Biology Senior High School, International Journal of Environmental and Science Education 12 (2017) 1719-1735.

[16] V. Sampson, L. Gleim, Argument-Driven Inquiry To Promote The Understanding of Important Concepts \& Practices in Biology, National Association of Biology Teachers 8 (2011) 465-472.

[17] J-P. Walker, V. Sampson, J. Grooms, ArgumentDriven Inquiry in Undergraduate Chemistry Labs: The Impact on Students' Conceptual Understanding, Argument Skills, and Attitudes Toward Science, Journal of College Science Teaching 41 (2011) 74-81.

[18] V. Sampson, J. Grooms, J.P. Walker, Argument-Driven Inquiry as A Way to Help Students Learn How to Participate in Scientific Argumentation and Craft Written Arguments: An Exploratory Study, Science Education 95 (2011) 217-257. DOI: https://doi.org/10.1002/sce.20421

[19] L. Farida, U. Rosidin, K. Herlina, N. Hasnunidah, Pengaruh Penerapan Model Pembelajaran Argument- Driven Inquiry (ADI) terhadap Keterampilan Argumentasi Siswa SMP Berdasarkan Perbedaan Jenis Kelamin, Journal of Physics and Science Learning 2 (2018) 1526.

[20] T. Demircioğlu, S. Uçar, The effect of argument-driven inquiry on pre-service science teachers' attitudes and argumentation skills, in: Procedia: Social and Behavioral Sciences, vol. 46, Elsevier, Amsterdam, 2012, pp. 5035-5039. DOI:

https://doi.org/10.1016/j.sbspro.2012.06.382

[21] J. Lightner, L. Tomaswick, Active LearningThink, Pair, Share, Kent State University Center for Teaching and Learning, 2017, pp. 5-7.

[22] V. Persaud, R. Persaud, Increasing Student Interactivity Using A Think-Pair-Share Model with A Web-Based Student Response System in A Large Lecture Class in Guyana, International Journal of Education and Development using Information and Communication Technology 15 (2019) 117-131.

[23] A. Kothiyal, R. Majumdar, S. Murthy, S. Iyer, Effect of think-pair-share in a large CS1 class, in: Proceedings of The Ninth Annual International ACM Conference on International Computing Education Research - ICER '13, 2013, 2019, p. 137, DOI: https://doi.org/10.1145/2493394.2493408

[24] A-A-A. Raba, The Influence of Think-PairShare (TPS) on Improving Students' Oral Communication Skills in EFL Classrooms, Creative Education 8 (2017) 12-23. DOI: https://doi.org/10.4236/ce.2017.81002

[25] A. G. Rodríguez, S. McKay, Professional Development for Experienced Teachers Working with Adult English Language Learners, CAELA Network Brief, 2010.

[26] L.W. Anderson, D.R. Krathwohl, P.W. Airasian, K.A. Cruikshank, R.E. Mayer, P.R. Pintrich, J. Raths, M.C. Wittrock, A Taxonomy for Learning, Teaching, and Assessing, Longman, 2001.

[27] P. Paidi, I. S. Mercuriani, B. Subali, Students' Competence in Cognitive Process and Knowledge in Biology Based on Curriculum Used in Indonesia, International Journal of Instruction 13 (2020) 491-510. DOI: https://doi.org/10.29333/iji.2020.13334a

[28] Y. Muntaza, A. C. Adi, Hubungan Sumber Informasi dan Pengalaman dengan Tingkat Pengetahuan Tentang Penggunaan Monosodium 
Glutamate (MSG) Pada Ibu Rumah Tangga, Amerta Nutrition (2020) 72-78. DOI: https://doi.org/10.2473/amnt.v4i1.2020.72-78

[29] Y. Jakaria, Pendidikan Guru Sekolah Dasar dengan Mata Pelajaran yang Diampu, Jurnal Pendidikan dan Kebudayaan 4 (2014) 499-514.

[30] P-M. Sadler, G. Sonnert, H.P. Coyle, N. CookSmith, J.L. Miller, The Influence of Teachers' Knowledge on Student Learning in Middle School Physical Science Classrooms, American Educational Research Journal 50 (2013) 10201049.

DOI: https://doi.org/10.3102/0002831213477680

[31] J. Julia, H. Subarjah, M. Maulana, A. Sujana, I. Isrokatun, D. Nugraha, D. Rachmatin, Readiness and Competence of New Teachers for Career as Professional Teachers in Primary Schools, European Journal of Educational Research, vol. 9, 2020, pp. 655-673. DOI: https://doi.org/10.12973/eu-jer.9.2.655

[32] S. R. Shah, U. S. Udgaonkar, Influence of Gender and Age of Teachers on Teaching: Students Perspective, International Journal of Current Microbiology and Applied Sciences 7 (2018) 2436-2441. DOI: https://doi.org/10.20546/ijcmas.2018.701.293

[33] C. Foster, J.A. Florhaug, J. Frankin, L. Gottschall, L.A. Hrovatin, S. Parker, P. Doleshal, C. Dodge, A New Approach to Monitoring Exercise Training, Journal of Strength and Conditioning Research 15 (2001) 109-115.

DOI: https://doi.org/10.1519/00124278-200102000$\underline{00019}$

[34] Z. Ünal, A. Ünal, The Impact of Years of Teaching Experience on The Classroom Management Approaches of Elementary School Teachers, International Journal of Instruction 5 (2012) 41-60.

[35] R.A.M. Ismail, R. Arshad, Z.Abas, Can Teachers' Age and Experience Influence Teacher Effectiveness in HOTS?, International Journal of Advanced Studies in Social Science and Innovation 2 (2018) 144-158. DOI: https://doi.org/10.30690/ijassi.21.11

[36] V. Isari, Z-M. Efendi, N. Neviyarni, Perbedaan Latar Belakang Pendidikan dan Masa Kerja Guru Bimbingan Dan Konseling Terhadap Pelaksanaan Layanan Bimbingan dan Konseling Format Klasikal, Jurnal Bikotetik: Bimbingan dan Konseling: Teori dan Praktik) 1 (2017) 2127.

DOI: https://doi.org/10.26740/bikotetik.v1n1.p21-29

[37] M. Yusuf, M-D. Hidayatullah, I-T. Pamungkas, R. Faizah, Analisis Hubungan Motivasi Belajar dengan Pemahaman Konsep Gerak Lurus Mahasiswa Pendidikan Fisika, Jurnal Riset Pendidikan Fisika 2 (2017) 49-55. DOI: http://dx.doi.org/10.17977

[38] S. W. T. Moalosi, Teachers Self Efficacy: Is Reporting Non-Significant Results Essential?, Journal of International Education Research, 9 (2013) 397-406. DOI: https://doi.org/10.19030/jier.v9i4.8266

[39] R-M. Klassen, V-M-C. Tze, S-M. Betts, K-A. Gordon, Teacher Efficacy Research 1998-2009: Signs of Progress or Unfulfilled Promise?, Educational Psychology Review 23 (2011) 2143. DOI: https://doi.org/10.1007/s10648-0109141-8

[40] Y. Yusrizal, C.Z. Harun, H. Husen, M. Iqbal, Performance Assessment of State Senior High School Teachers Aged 56 Years and Above, International Journal of Instruction 11 (2018) 33-46.

DOI: https://doi.org/10.12973/iji.2018.1113a

[41] S.W. Joye, J.H. Wilson, Professor Age and Gender Affect Student Perceptions and Grades, Journal of the Scholarship of Teaching and Learning $15 \quad$ (2015) 126-138. DOI: https://doi.org/http:/dx.doi.org/10.17977

[42] P.A. Joan, I.E. Henry, Influence of Teachers' Age, Marital Status and Gender on Students' Accademic Achievement, Asian Journal of Educational Research 3 (2015) 60. 